\title{
Pengaruh Kemampuan dan Keterlibatan Pengguna Terhadap Kinerja Sistem Informasi Pengelolaan Keuangan Daerah
}

\author{
Putu Bayu Eka Yustikarana ${ }^{1}$ \\ Made Gede Wirakusuma ${ }^{2}$
}

\author{
${ }^{1,2}$ Fakultas Ekonomi dan Bisnis Universitas Udayana (Unud), Bali, Indonesia \\ e-mail: yustikarana@gmail.com
}

\begin{abstract}
ABSTRAK
Salah satu wujud penerapan pemanfaatan teknologi informasi yang dilakukan pemerintah di dinas pariwisata provinsi bali adalah meningkatkan pengelolaan keuangan daerah dengan menggunakan Sistem Informasi Pengelolaan Keuangan Daerah (SIPKD). Terdapat beberapa kendala dalam penerapan sistem tersebut diantaranya yaitu para pengguna masih kurang yang terlibat dalam menggunakan sistem tersebut. Kurangnya pemahaman dan kendala teknis berupa jaringan pendukung dalam penggunaan SIPKD, yang berunjung pada keterlambatan dalam penyampaian laporan keuangan dan laporan pertanggung jawaban. Tujuan penelitian adalah untuk mengetahui seberapa besar pengaruh kemampuan pengguna dan keterlibatan pengguna pada kinerja Sistem Informasi Pengelolaan Keuangan Daerah (SIPKD). Metode pemilihan sampel dalam penelitian ini menggunakan teknik sampel jenuh (sensus). Jumlah sampel dalam penelitian ini adalah sebanyak 40 orang. Hasil penelitian ini diketahui bahwa kemampuan pengguna dan keterlibatan pengguna berpengaruh positif dan signifikan terhadap kinerja SIPKD di Dinas Pariwisata Provinsi Bali.
\end{abstract}

Kata Kunci: Keterlibatan pengguna, kemampuan pengguna, kinerja SIPKD

\begin{abstract}
One manifestation of the application of information technology carried out by the government in the Bali provincial tourism office is improving regional financial management using the Regional Financial Management Information System (SIPKD). Partially needed in the implementation of the system for users who are not involved in the system. Lack of understanding and technical support involving support in the use of SIPKD, which leads to delays in submitting financial reports and answer accountability reports. The aim of the study was to study most user needs and support users in the Regional Financial Management Information System (SIPKD). The method of selecting samples in this study used a saturated sample technique (census). The number of samples in this study were 40 people. Based on published research results regarding the user's ability and positive and significant user support for the performance of SIPKD at the Bali Provincial Tourism Office.
\end{abstract}

Keywords: Use users, user capabilities, SIPKD performance

\section{PENDAHULUAN}

Penerapan teknologi Informasi (TI) yang dikembangkan dalam pemerintahan atau yang disebut dengan e-government membuat masyarakat semakin mudah dalam mengakses kebijakan pemerintah sehingga program yang dirancangkan 
pemerintah dapat berjalan dengan lancar dan efisien. Penerapan TI di sektor publik telah memberi manfaat bagi organisasi pemerintah atau masyarakat, namun dalam penerapan TI di sektor publik dimungkinkan terjadinya kegagalan. Berdasarkan penelitian di New Zealand, yang dilakukan oleh (Goldfinch, 2007), menunjukkan bahwa 38\% proyek sistem di pemerintah berhasil, 59\% bermasalah, dan $3 \%$ gagal atau dibatalkan. Hal ini menunjukkan bahwa penerapan sistem di organisasi sektor publik perlu lebih hatihati karena adanya benturan kepentingan antara birokrasi, manajerial, dan programmer.

Sistem informasi yang terkomputerisasi seakan menjadi suatu keharusan bagi perusahaan saat ini, karena mampu memberikan dukungan dalam menyajikan informasi keuangan dan non keuangan secara lebih praktis dan efisien. Sistem informasi adalah sistem yang digunakan organisasi untuk mengenali, mendapatkan dan mempertukarkan informasi lintas waktu dan tempat dalam bentuk yang memungkinkan orang untuk melaksanakan tanggung jawab mereka (Swandewi dan Dodik, 2017).

Sistem Informasi Akuntansi (SIA) merupakan hal yang penting bagi sebuah instansi pemerintahan, adanya SIA membuat sebuah instansi pemerintahan mampu melakukan pengendalian dan memudahkan instansi tersebut dalam meningkatkan kinerjanya. Sistem akuntansi bertanggung jawab dalam menganalisa dan memantau kondisi keuangan sebuah perusahaan, persiapan dokumen yang diperlukan untuk keperluan pajak, memberikan informasi untuk mendukung banyak fungsi organisasi lainnya seperti produksi, pemasaran, sumber daya manusia manajemen, dan perencanaan strategis (Harash et al., 2014). Tujuan dalam penyusunan suatu sistem informasi akuntansi antara lain untuk 
menyediakan informasi bagi pengelolaan kegiatan keuangan, memperbaiki informasi yang dihasilkan oleh sistem yang sudah ada, baik mengenai mutu, ketepatan penyajian maupun struktur informasinya. Selain itu tujuan sistem informasi akuntansi adalah untuk memperbaiki tingkat keandalan (reliability). (Kharisma, 2017).

Dalam penelitian Murty dan Hudiwinarsih (2012) dikatakan bahwa kinerja merupakan pencapaian usaha seseorang guna mewujudkan visi, misi dan tujuan organisasi. Kinerja sistem informasi akuntansi dapat dipengaruhi oleh beberapa faktor, Choe (1996) mengungkapkan bahwa terdapat beberapa faktor yang berpengaruh terhadap kinerja sistem informasi akuntansi, yaitu keterlibatan pengguna, kemampuan pengguna sistem informasi, dan ketentuan pelatihan dan pendidikan pengguna sistem informasi. (Fung, 2002) dalam penelitiannya menyebutkan delapan faktor yang digunakan dalam pengukuran kinerja SIA, yaitu keterlibatan pengguna dalam pengembangan sistem, kemampuan teknik personal sistem informasi, ukuran organisasi, dukungan manajemen puncak, formalisasi pengembangan sistem informasi, program pelatihan dan pendidikan pengguna, keberadaan dewan pengarah sistem informasi dan lokasi dari departemen sistem informasi.

Hal terpenting dari keberhasilan penerapan teknologi informasi atau sistem informasi, selain perangkat keras dan perangkat lunak adalah pengguna teknologi sehingga aspek keperilakuan pengguna menjadi penting dan diperhatikan dalam penerapan teknologi informasi (Suarta dan Sudiadnyani, 2014). Pengguna (user) adalah aktor penting dalam penerapan teknologi informasi atau sistem informasi (Dominggus et al. 2013). Kemampuan pengguna sistem informasi dalam 
Putu Bayu Eka Yustikarana dan Made Gede Wirakusuma. Pengaruh ...

mengoperasikan sistem informasi sangat dibutuhkan agar sistem dapat beroperasi secara maksimal, yang dapat dilihat dari bagaimana pengguna sistem menjalankan Sistem Informasi Akuntansi yang ada.

Penerapan sistem akuntansi berkomputer, kemampuan pengguna harus diselaraskan dengan sistem yang akan diterapkan dan ikut terlibat dalam sistem. Dengan demikian, sistem tersebut dapat berjalan secara efektif sesuai dengan tujuan yang hendak dicapai oleh perusahaan. Hal ini sejalan dengan penelitian Komara (2005), Perbarini dan Juliarsa (2012) menemukan ada pengaruh positif dan signifikan antara variabel keterlibatan pengguna dalam pengembangan Sistem Informasi Akuntansi (Lilis Puspitawati, 2011).

Bali merupakan salah satu daerah tujuan wisata yang paling banyak dikunjungi oleh wisatawan, baik oleh wisatawan mancanegara maupun wisatawan domestik. Hal ini terlihat dari jumlah kunjungan wisatawan, baik wisatawan mancanegara maupun wisatawan domestik yang datang ke Bali dari tahun 20152017 yang terlihat pada grafik dibawah ini.

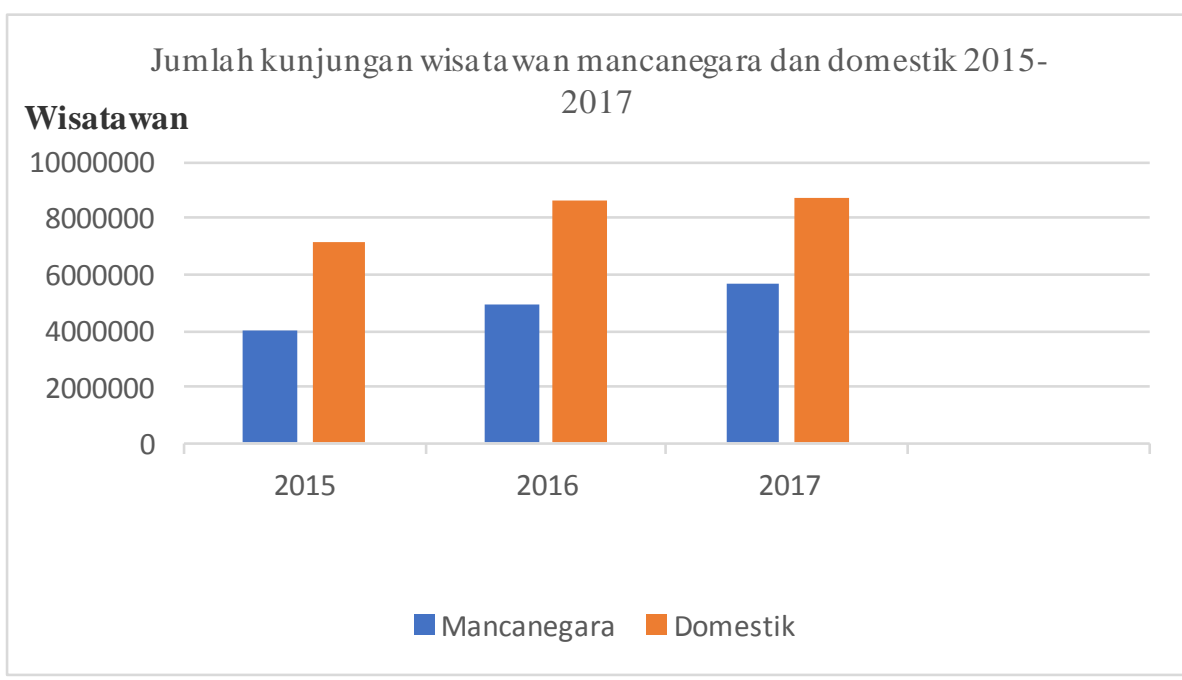

Gambar 1. Jumlah Kunjungan Wisatawan Mancanegara Dan Domestik Ke Bali Tahun 2015-2017

Sumber: Dinas Pariwisata Provinsi Bali, 2018 
Dapat terlihat pada grafik diatas terjadi peningkatan jumlah kunjungan wisatawan mancanegara dan domestik 2015-2017. Kenaikan jumlah kunjungan wisatawan mancanegara dan domestik mencerminkan bahwa Bali menjadi daya tarik yang kuat bagi wisatawan untuk berwisata. (Dinas Pariwisata Provinsi Bali, 2018). Peningkatan jumlah wisatawan mancanegara dan domestik yang datang ke Bali tidak terlepas dari usaha-usaha yang dilakukan oleh Dinas Pariwisata Provinsi Bali.

Dinas Pariwisata Provinsi Bali sebagai regulator dan pengorganisasian aturan-aturan yang mendukung pariwisata di Bali yang sangat berperan penting untuk kemajuan kepariwisataan, dimana Dinas Pariwisata menggali dan mengembangkan potensi-potensi yang ada di Bali sehingga menjadi daya tarik wisata yang menarik dalam meningkatkan perekonomian di Bali. Banyaknya wisatawan berkunjung di Bali menuntut pengguna sistem informasi akuntansi khususnya di Dinas Pariwisata Provinsi Bali agar memiliki kemampuan yang baik dalam mengelola sistem sehingga informasi yang dihasilkan dari proses pengeleloaan data dapat lebih akurat.

Dalam rangka meningkatkan pengelolaan sumber daya dan mewujudkan tata kelola pemerintahan yang baik (good governance), pemerintah berusaha mewujudkan pelayanan prima kepada masyarakat dengan cara membangun tekonologi informasi di bidang keuangan berkaitan dengan pengelolaan keuangan daerah (Margan Kesumman, 2016). Salah satu wujud penerapan pemanfaatan teknologi informasi yang dilakukan pemerintah khususnya di dinas pariwisata provinsi bali adalah meningkatkan pengelolaan keuangan daerah dengan menggunakan Sistem Informasi Pengelolaan Keuangan Daerah (SIPKD). Dinas 
Putu Bayu Eka Yustikarana dan Made Gede Wirakusuma. Pengaruh ...

Pariwisata Provinsi Bali membutuhkan perencanaan dan anggaran sebelum mengadakan suatu pelatihan serta adanya proses pencatatan keuangan setelah mengadakan suatu pelatihan. Perencanaan dan anggaran serta pencatatan keuangan dibantu dengan adanya sistem akuntansi yang terkomputerisasi yaitu SIPKD.

SIPKD merupakan aplikasi yang dibangun oleh Ditjen Keuangan Daerah Kementrian Dalam Negeri Republik Indonesia dalam rangka percepatan transfer data dan efisiensi dalam penghimpunan data keuangan daerah. Sistem informasi pengelolaan keuangan daerah merupakan aplikasi terpadu yang dipergunakan sebagai alat bantu pemerintah daerah yang digunakan meningkatkan efektifitas implementasi dari berbagai regulasi bidang pengelolaan keuangan daerah yang berdasarkan pada asas efesiensi, ekonomis, efektif, transparan, akuntabel dan auditable (www.djkd.kemendagri.go.id: 2018).

Penerapan SIPKD di Dinas Pariwisata Provinsi Bali dapat bermanfaat untuk mengolah data-data mengenai informasi tentang jumlah kunjungan wisatawan, lama tinggal dan pengeluaran wisatawan selama berada di Bali yang nantinya akan bermanfaat dalam menghitung Pajak Hotel dan Restoran (PHR) secara akuntabel sehingga berkontribusi pada pembangunan pariwisata di Bali.

Dalam penerapan sistem tersebut terhadap Dinas Pariwisata Provinsi Bali terdapat beberapa kendala diantaranya pada sumber daya manusia (SDM), yaitu para pengguna masih kurang yang terlibat dalam menggunakan sistem tersebut karena perubahan cara kerja dari sistem manual menjadi sistem yang berbasis pada teknologi informasi membuat para pengguna tidak mudah melakukan koreksi jika terjadi kesalahan. Kurangnya pemahaman, kesalahan dalam 
mengentry data (human error) dan kendala teknis berupa jaringan pendukung dalam penggunaan SIPKD menjadi permasalahan yang berunjung pada keterlambatan dalam penyampaian laporan keuangan dan laporan pertanggung jawaban (Trenida, 2018).

Berdasarkan paparan diatas peneliti memilih lokasi penelitian di Dinas Pariwisata Provinsi Bali karena Dinas Pariwisata Provinsi Bali bertugas melakukan pengelolaan pariwisata di Provinsi Bali dan mewujudkan pelayanan yang baik untuk masyarakat sehingga dibutuhkan penggunaan SIPKD dalam memproses atau mengolah data untuk menghasilkan informasi yang dibutuhkan dalam meningkatkan pelayanan dan tata kelola pariwisata di Provinsi Bali.

Keterlibatan Pegawai Dinas Pariwisata Provinsi Bali dalam penyusunan SIPKD dan penggunaan pada sistem tersebut masih dirasa kurang dan jika dilihat dari karakteristik responden menunjukan bahwa mayoritas pengguna SIPKD masih berpendidikan trakhir SMA/D4 menunjukan minimnya kemampuan pengguna dalam mengelola SIPKD. Keunikan penelitian ini dibandingkan dengan penelitian sebelumnya adalah penelitian ini mengambil tempat di Dinas Pariwisata Provinsi Bali mengingat Dinas Pariwisata Provinsi Bali yang belum pernah diteliti oleh peneliti sebelumnya (Dinas Pariwisata Provinsi Bali, 2018).

Penelitian mengenai kinerja sistem infomasi pengelolaan keuangan daerah telah dilakukan oleh beberapa peneliti diantaranya; Wansyah et al. (2012), Gomes et al. (2013) dan Ariani (2017) dikatakan bahwa pengelolaan keuangan daerah sudah seharusnya didukung oleh sumber daya manusia yang baik dengan latar pendidikan yang sesuai dengan bidang keuangan, pernah mengikuti pendidikan dan pelatihan terkait pengelolaan keuangan serta pengalaman yang 
cukup di bidang tersebut sehingga kinerja dalam pengelolaan keuangan daerah tercapai. Staf yang bertugas dalam bidang perencanaan dan penatausahaan keuangan sudah seharusnya memiliki latar belakang pendidikan di bidang ekonomi, serta pendidikan dan pelatihan mengenai pengelolaan keuangan daerah, disamping pengalam di bidang tersebut agar proses kegiatan perencanaan dan penatausahaan keuangan dapat berjalan dengan baik. Dengan berkembangnya teknologi, saat ini hanya sedikit SDM yang belum memahami teknologi komputer.

Almilia dan Briliantien (2007) mengemukakan dari penelitian yang sudah dilakukan, faktor-faktor yang mempengaruhi kinerja SIA hanya dukungan manajemen puncak sedangkan faktor-faktor lainnya seperti program pelatihan dan pendidikan, keterlibatan pengguna serta kemampuan teknik personal tidak berpengaruh terhadap kinerja SIA. Menurut Kharisma (2017) dalam penelitiannya hanya pelatihan dan pendidikan pengguna yang tidak berpengaruh terhadap kinerja sistem informasi akuntansi sedangkan keterlibatan pengguna dan kemampuan pengguna berpengaruh positif dan signifikan terhadap kinerja sistem informasi akuntansi.

Perbarini dan Juliarsa (2012) dalam penelitiannya mendapatkan hasil bahwa Keterlibatan Pemakai, Kemampuan Teknik Personal, serta Program Pendidikan dan Pelatihan berpengaruh signifikan terhadap kinerja SIA. Penelitian tersebut juga mendapatkan hasil yang sama dengan penelitian yang dilakukan oleh Surya dan Suardhika (2016) bahwa pelatihan dan pendidikan, dukungan manajemen puncak, pengembangan sistem informasi, dan keterlibatan pemakai berpengaruh 
positif dan signifikan terhadap kinerja SIA yang diukur dengan kepuasan pemakai.

Ives et al (1983) menyatakan bahwa kepuasan pengguna sistem menunjukan seberapa jauh pengguna puas dan percaya sistem informasi yang disediakan untuk memenuhi kebutuhan mereka. Semakin tinggi tingkat kepuasan pengguna terhadap sistem informasi akuntansi yang dioperasikan maka semakin tinggi kinerja dari sistem informasi akuntansi tersebut. Terry (2004) dalam Artanaya (2016) menyatakan bahwa kepuasan pengguna akan meningkat apabila didukung oleh keterlibatan pengguna itu sendiri. Kepuasan dari pengguna sistem informasi akuntansi menunjukan seberapa senang pengguna dalam menggunakan sistem informasi untuk menghasilkan informasi yang sesuai dengan kebutuhannya. Galang (2014) mendapatkan hasil bahwa hanya program pelatihan dan pendidikan yang berpengaruh positif terhadap kinerja SIA, dan keterlibatan pengguna dan kemampuan teknik personal tidak berpengaruh positif dan signifikan terhadap kinerja SIA. Hari (2014) yang menyatakan bahwa dukungan manajemen puncak tidak berpengaruh terhadap kinerja SIA, sedangkan keterlibatan pengguna serta program pelatihan berpengaruh terhadap kinerja SIA.

Ketidakkonsistenan dari hasil penelitian-penelitian sebelumnya tentang topik yang di angkat peneliti, mendorong peneliti untuk mengkaji lebih lanjut mengenai pengaruh kemampuan dan keterlibatan pengguna terhadap kinerja sistem informasi pengelolaan keuangan daerah (SIPKD) khususnya di Dinas Pariwisata Provinsi Bali.

Kemampuan pengguna sistem informasi pengelolaan keuangan daerah (SIPKD) mempunyai peranan yang penting di dalam pengembangan sistem 
informasi guna menciptakan laporan perencanaan yang akurat sehingga setiap karyawan harus mampu menguasai penggunaan sistem berbasis komputer agar dapat memproses sejumlah transaksi dengan cepat dan terintegrasi, dapat menyimpan data dan mengambil data dalam jumlah yang besar, dapat mengurangi kesalahan matematik, menghasilkan laporan tepat waktu dalam berbagai bentuk, serta dapat menjadi alat bantu keputusan.

Berdasarkan Teori TAM menyatakan bahwa hubungan antara kemampuan pengguna terhadap kinerja SIPKD berpengaruh positif karena pengguna sistem informasi yang memiliki kemampuan dalam mengoperasikan suatu SIPKD akan meningkatkan kinerja dari sistem informasi tersebut. Tentu saja apabila pengguna sistem informasi tersebut tidak memiliki kemampuan dalam mengoperasikan sistem tersebut maka sistem informasi tersebut tidak akan beroperasi secara maksimal.

Kharisma (2017) dalam penelitiannya mendapatkan hasil bahwa kemampuan pengguna berpengaruh terhadap kinerja sistem informasi akuntansi. Penelitian tersebut konsisten dengan Perbarini dan Juliarsa (2012) yaitu kemampuan pengguna berpengaruh signifikan terhadap kinerja sistem informasi akuntansi. Berbeda dengan penelitian yang dilakukan oleh Galang (2014) yang mendapatkan hasil bahwa kemampuan pengguna tidak berpengaruh terhadap kinerja sistem informasi akuntansi. Berdasarkan penelitian-penelitian terdahulu maka, hipotesis satu dinyatakan sebagai berikut:

$\mathrm{H}_{1}$ : Kemampuan pengguna berpengaruh positif terhadap kinerja sistem informasi pengelolaan keuangan daerah (SIPKD). 
Dalam Teori TAM menyatakan hubungan antara keterlibatan pengguna terhadap sistem informasi pengelolaan keuangan daerah (SIPKD) berpengaruh positif karena sistem informasi tidak akan bisa beroperasi tanpa adanya pengguna yang terlibat dalam mengoperasikan sistem informasi tersebut oleh karena itu keterlibatan pengguna dalam hal ini pegawai di Dinas Pariwisata Provinsi Bali menunjang keberhasilan penerapan SIPKD.

Komara (2005), Perbarini dan Juliarsa (2012) menemukan bahwa keterlibatan pengguna dalam pengembangan sistem informasi akuntansi berpengaruh terhadap kinerja sistem informasi akuntansi. (Kharisma, 2017) dalam penelitiannya mendapatkan hasil bahwa keterlibatan pengguna berpengaruh positif terhadap kinerja sistem informasi akuntansi. Penelitian tersebut konsisten dengan hasil dari penelitian (Surya dan Suardhika, 2016) bahwa keterlibatan pengguna berpengaruh positif terhadap kinerja sistem informasi akuntansi. Berdasarkan uraian diatas, maka hipotesis satu dinyatakan sebagai berikut:

$\mathrm{H}_{2}$ : Keterlibatan pengguna berpengaruh positif terhadap kinerja sistem informasi pengelolaan keuangan daerah (SIPKD).

\section{METODE PENELITIAN}

Penelitian ini merupakan penelitian kuantitatif dengan bentuk asosiatif. Penelitian kuantitatif merupakan penelitian yang menggunakan data berupa angka serta dianalisis menggunakan alat statistik (Indriantoro, 2013;12). Penelitian berjenis asosiatif merupakan penelitian yang bertujuan untuk mengetahui hubungan antara dua variabel atau lebih. Desain penelitian sebagai berikut. 


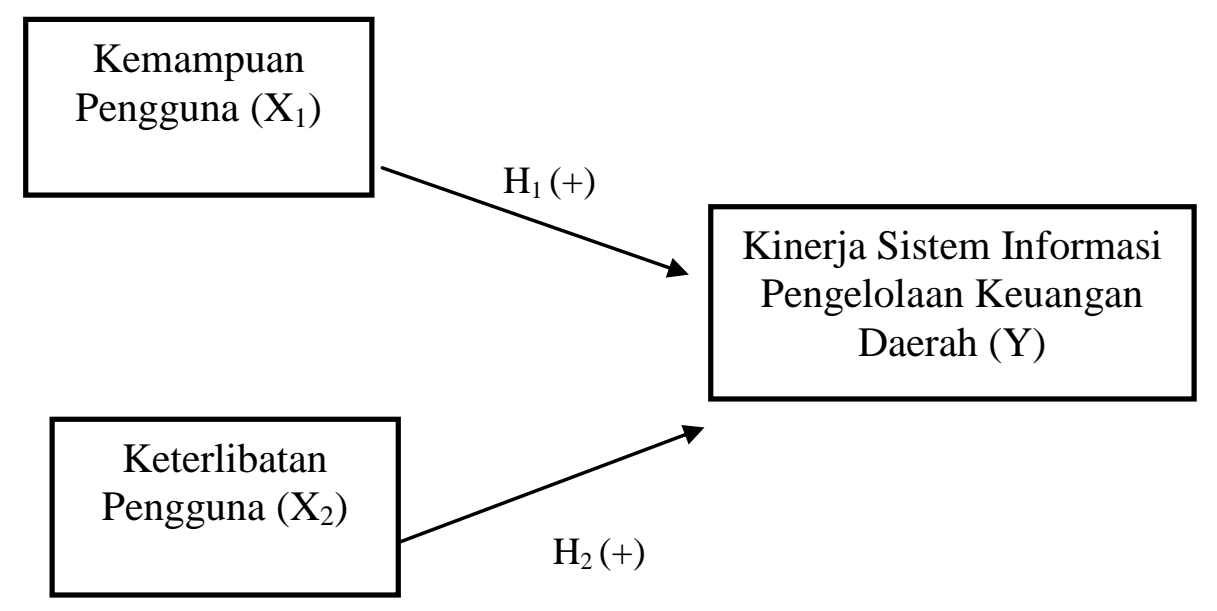

Sumber :

\section{Gambar 2. Desain Penelitian}

$\mathrm{H}_{1}$ : Kharisma (2017), Perbarini dan Juliarsa (2012), Galang (2014)

$\mathrm{H}_{2}$ : Komara (2005), Perbarini dan Juliarsa (2012), Kharisma (2017), Surya dan Suardhika (2016)

Lokasi penelitian dilakukan pada Kantor Dinas Pariwisata Provinsi Bali yang berada di Jalan S. Parman, Niti Mandala Renon. Sedangkan obyek dalam penelitian ini adalah Kinerja Sistem Informasi Pengelolaan Keuangan Daerah di Dinas Pariwisata Provinsi Bali.

Variabel terikat dalam penelitian ini adalah Kinerja Sistem Informasi Pengelolaan Keuangan Keuangan Daerah (Y). Variabel ini diukur dengan menggunakan dua indikator yaitu kepuasan dan pelatihan pengguna yang masingmasing terdapat delapan dan lima pernyataan dengan menggunakan instrument yang dikembangkan oleh Almilia dan Briliantien (2007) dalam Kharisma (2017) dengan skala Likert Modifikasi, yaitu 1) sangat tidak setuju diberi skor 1,2) tidak setuju diberi skor 2, 3) setuju diberi skor 3, dan 4) sangat setuju diberi skor 4.

Variabel bebas dalam penelitian ini adalah Kemampuan $\left(\mathrm{X}_{1}\right)$ Dan Keterlibatan Pengguna $\left(\mathrm{X}_{2}\right)$. Kemampuan $\left(\mathrm{X}_{1}\right)$ diukur dengan tiga pernyataan dengan menggunakan instrumen yang dikembangkan oleh Almilia dan Briliantien (2007) dalam Kharisma (2017). Keterlibatan Pengguna $\left(\mathrm{X}_{2}\right)$ diukur dengan empat 
pernyataan dengan menggunakan instrument yang dikembangkan oleh Almilia dan Briliantien (2007) dalam Kharisma (2017).

Populasi dalam penelitian ini adalah seluruh pengguna (SIPKD) yang bekerja di Dinas Pariwisata Provinsi Bali. Teknik penetapan sampel yang digunakan adalah teknik sampel jenuh (sensus) menurut Sugiyono (2014:61) sampel jenuh adalah teknik penentuan sampel bila semua anggota populasi digunakan sebagai sampel. Hal ini terjadi pada DISPARDA yang memiliki jumlah populasi yang kecil yaitu seluruh pegawai negeri sipil yang terlibat dalam sistem informasi pengelolaan keuangan daerah di Dinas Pariwisata Provinsi Bali, jadi jumlah sampel dan jumlah populasi sebanyak 40 orang.

Pengumpulan data dalam penelitian ini menggunakan kuesioner. Kuesioner yang digunakan dalam penelitian ini diukur menggunakan skala Likert modifikasi dengan skor 1 sampai 4. Jenis data yang digunakan dalam penelitian ini adalah data kuantitatif berupa jumlah pengguna sistem informasi pengelolaan keuangan daerah di Dinas Pariwisata Provinsi Bali. Data kualitatif dalam penelitian ini berupa nama, sejarah, dan struktur organisasi Dinas Pariwisata Provinsi Bali. Sedangkan sumber data yang digunakan dalam penelitian ini adalah data primer meliputi jawaban dari responden atas pernyataan kuesioner yang disebarkan oleh peneliti. Data sekunder dalam penelitian ini berupa sejarah dan struktur organisasi Dinas Pariwisata Provinsi Bali.

Teknik analisis data yang digunakan dalam penelitian ini adalah teknik analisis regresi linier berganda. Sebelum melakukan pengujian regresi, terdapat beberapa asumsi yang harus dipenuhi agar data yang akan dimasukkan dalam model regresi telah memenuhi ketentuan dan syarat dalam regresi. Uji asumsi 
klasik dalam penelitian ini mencakup uji normalitas, multikolinearitas, dan heteroskedastisitas. Model regresi linier berganda dirumuskan sebagai berikut.

$$
\mathrm{Y}=\alpha+\beta_{1} \mathrm{X}_{1}+\beta_{2} \mathrm{X}_{2}+\mathrm{e}
$$

Keterangan:

$\mathrm{Y} \quad=$ Kinerja sistem informasi pengelolaan keuangan daerah

$\alpha \quad=$ Konstan

$\mathrm{X}_{1}=$ Kemampuan pengguna

$\mathrm{X}_{2}=$ Keterlibatan pengguna

$\beta_{1} \quad=$ Koefisien regresi kemampuan pengguna

$\beta_{2} \quad=$ Koefisien regresi keterlibatan pengguna

$\mathrm{e} \quad=$ Komponen error

\section{HASIL DAN PEMBAHASAN}

Kuesioner dibagikan kepada 40 pengguna SIPKD di Dinas Pariwisata Provinsi Bali.Karakteristik responden dalam penelitian ini ditinjau berdasarkan jenis kelamin, umur, pendidikan terakhir, pengalaman bekerja.

Tabel 1.

Karakteristik Responden

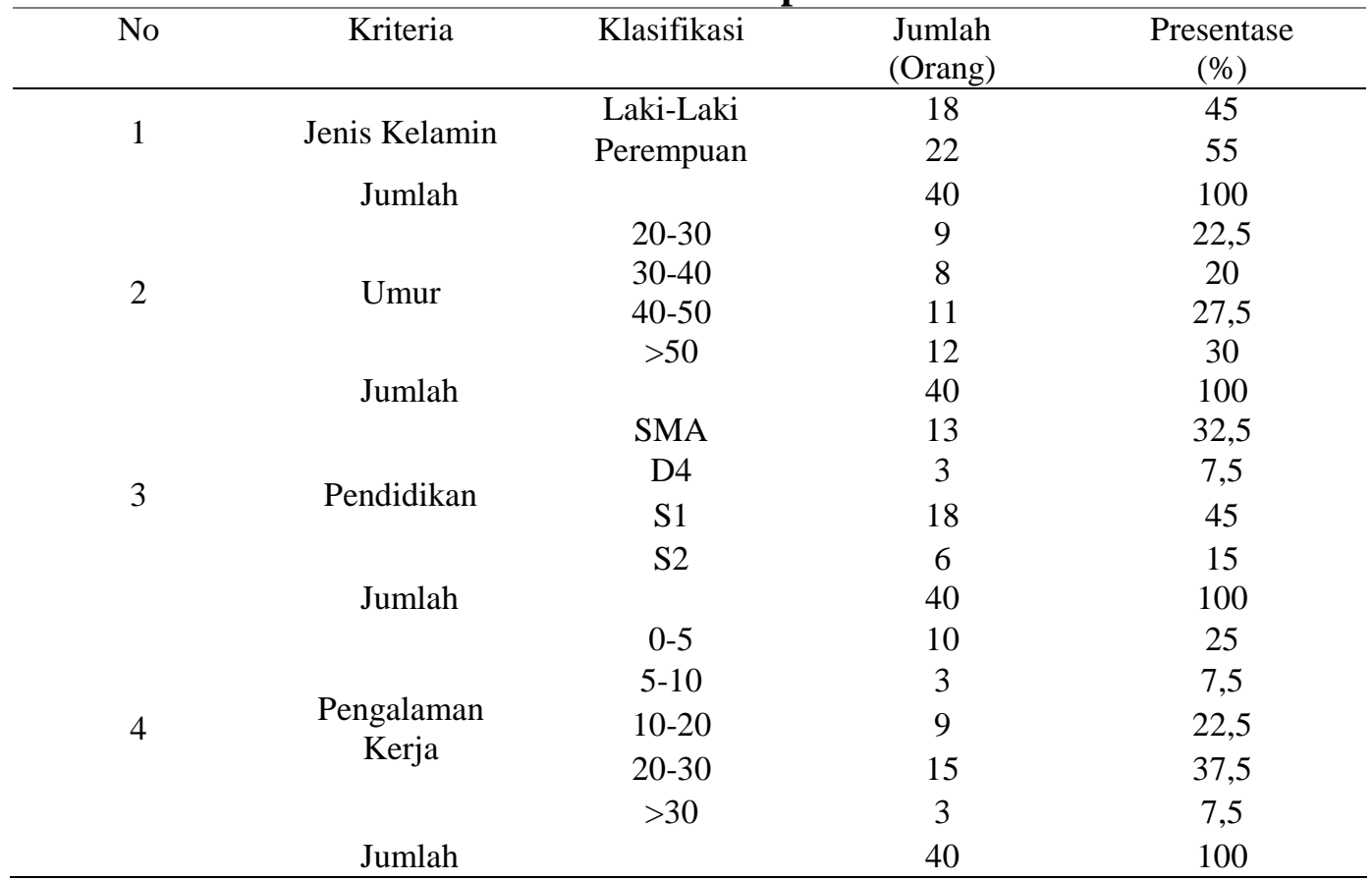

Sumber : Data diolah, 2018 
Berdasarkan tabel 1. data karakteristik responden yang meliputi jenis kelamin, umur, pendidikan terakhir, pengalaman bekerja dapat diuraikan sebagai berikut yaitu karakteristik responden berdasarkan jenis kelamin menjelaskan mengenai pengguna SIPKD laki-laki dan perempuan. Tabel 1. menunjukan bahwa mayoritas responden adalah perempuan sebanyak 22 orang (55\%) dan jumlah responden laki - laki sebanyak 18 orang (45\%).

Karakteristik responden berdasarkan umur para pengguna SIPKD di Dinas Pariwisata. Tabel 1. menunjukan umur 20-30 tahun sebanyak 9 orang (22,5\%), umur 30-40 tahun sekitar 8 orang (20\%), umur 40-50 sebanyak 11 orang $(27,5)$, dan diatas 50 tahun sebanyak 12 orang (30\%).

Karakteristik responden berdasarkan pendidikan terakhir untuk mengetahui tingkat pemahaman intelektual responden. Tabel 1. menunjukan bahwa mayoritas responden berpendidikan terakhir S1 sebanyak 18 orang (45\%), berpendidikan S2 sebanyak 6 orang (15\%), berpendidikan SMA sebanyak 13 orang (32,5\%), dan berpendidikan D4 sebanyak 3 orang (7,5\%).

Karakteristik responden berdasarkan pengalaman bekerja untuk mengetahui lamanya pengguna SIPKD tersebut bekerja di Dinas Pariwisata. Tabel 1. menunjukan bahwa diantaranya terdapat auditor yang bekerja selama 0-5 tahun sebanyak 10 orang (25\%), 5-10 tahun sebanyak 3 orang (7,5\%), 10-20 tahun sebanyak 9 orang $(22,5 \%)$, selama $20-30$ tahun sebanyak 15 orang $(37,5 \%)$, dan diatas 30 tahun sebanyak 3 orang $(7,5 \%)$.

Suatu instrumen dikatakan valid apabila memiliki koefisien lebih besar dari 0,30 dengan tingkat kesalahan Alpha 0,05. Hasil rekapitulasi uji validitas dalam penelitian ini disajikan dalam Tabel 2. 
Hasil uji validitas pada Tabel 2. menunjukkan bahwa indikator penelitian yang digunakan untuk mengukur variabelkemampuan pengguna, keterlibatan pengguna, dan kinerja sistem informasi pengelolaan keuangan daerah (SIPKD) memiliki nilai koefisien korelasi dengan skor total seluruh butir pernyataan lebih besar dari 0,30 dengan signifikansi kurang dari 0,05. Hal ini menunjukkan bahwa butir-butir pernyataan dalam instrumen penelitian tersebut valid dan layak digunakan sebagai instrument penelitian.

Tabel 2.

Rekapitulasi Hasil Uji Validitas Instrumen Penelitian

\begin{tabular}{|c|c|c|c|c|}
\hline Variabel & Indikator & Koefisien Korelasi & Sig. (2-tailed) & Keterangan \\
\hline Kemampuan & $\mathrm{X}_{1.1}$ & 0,767 & 0,000 & Valid \\
\hline Pengguna & $\mathrm{X}_{1.2}$ & 0,915 & 0,000 & Valid \\
\hline$\left(\mathrm{X}_{1}\right)$ & $\mathrm{X}_{1.3}$ & 0,796 & 0,000 & Valid \\
\hline \multirow{9}{*}{$\begin{array}{l}\text { Keterlibatan } \\
\text { Pengguna } \\
\left(\mathrm{X}_{2}\right)\end{array}$} & $X_{2.1}$ & 0,792 & 0,000 & Valid \\
\hline & $X_{2.2}$ & 0,853 & 0,000 & Valid \\
\hline & $X_{2.3}$ & 0,762 & 0,000 & Valid \\
\hline & $X_{2.4}$ & 0,696 & 0,000 & Valid \\
\hline & $Y_{1}$ & 0,830 & 0,000 & Valid \\
\hline & $Y_{2}$ & 0,923 & 0,000 & Valid \\
\hline & $Y_{3}$ & 0,858 & 0,000 & Valid \\
\hline & $Y_{4}$ & 0,723 & 0,000 & Valid \\
\hline & $Y_{5}$ & 0,767 & 0,000 & Valid \\
\hline \multirow{8}{*}{$\begin{array}{c}\text { Kinerja } \\
\text { SIPKD } \\
(\mathrm{Y})\end{array}$} & $Y_{6}$ & 0,871 & 0,000 & Valid \\
\hline & $Y_{7}$ & 0,923 & 0,000 & Valid \\
\hline & $Y_{8}$ & 0,789 & 0,000 & Valid \\
\hline & $Y_{9}$ & 0,803 & 0,000 & Valid \\
\hline & $Y_{10}$ & 0,842 & 0,000 & Valid \\
\hline & $Y_{11}$ & 0,798 & 0,000 & Valid \\
\hline & $Y_{12}$ & 0,858 & 0,000 & Valid \\
\hline & $Y_{13}$ & 0,752 & 0,000 & Valid \\
\hline
\end{tabular}

Sumber : Data diolah, 2018

Uji Reliabilitas terhadap instrumen penelitian ini menggunakan nilai Cronbach's Alpha. Nilai Alpha Cronbach dinyatakan reliabel jika nilainya lebih besar atau sama dengan 0,60. Rekapitulasi hasil uji reliabilitas instrumen penelitian dapat dilihat pada Tabel 3 . 
Tabel 3.

Rekapitulasi Hasil Uji Reliabilitas Instrumen Penelitian

\begin{tabular}{cccc}
\hline No. & Variabel & Cronbach's Alpha & Keterangan \\
\hline 1 & Kemampuan pengguna $\left(\mathrm{X}_{1}\right)$ & 0,772 & Reliabel \\
2 & Keterlibatan pengguna $\left(\mathrm{X}_{2}\right)$ & 0,776 & Reliabel \\
3 & Kinerja SIPKD $(\mathrm{Y})$ & 0,960 & Reliabel \\
\hline \multicolumn{2}{l}{ Sumber : Data diolah, 2018 }
\end{tabular}

Hasil uji reliabilitas yang disajikan pada Tabel 3. menunjukkan bahwa variabel penelitian memiliki koefisien Cronbach's Alpha lebih dari 0,60. Jadi dapat dinyatakan bahwa seluruh variabel telah memenuhi syarat reliabilitas atau kehandalan sehingga dapat digunakan untuk dianalisis lebih lanjut.

Analisis statistik deskriptif dipergunakan untuk menggambarkan atau menjelaskan suatu data pada variabel penelitian berdasarkan jumlah sampel, nilai rata - rata (mean), standar deviasi, nilai maksimum, dan nilai minimum.

Tabel 4.

Hasil Statistik Deskriptif

\begin{tabular}{cccccc}
\hline Variabel & N & Min. & Max. & Mean & Std. Deviasi \\
\hline Kemampuan Pengguna & 40 & 2,33 & 4,00 & 29,9 & 0,51253 \\
Keterlibatan Pengguna & 40 & 1,75 & 3,75 & 28,3 & 0,58439 \\
Kinerja SIPKD & 40 & 2,15 & 3,92 & 31,3 & 0,45981 \\
\hline
\end{tabular}
Sumber : Data diolah, 2018

Berdasarkan Tabel 4. dapat diuraikan yaitu kemampuan Pengguna $\left(\mathrm{X}_{1}\right)$ memiliki nilai minimum sebesar 2,33 pada data nomor 1 , serta nilai maksimum sebesar 4,00 pada data nomor 14,25,26,27 dengan nilai rata - rata 29,9 menunjukan jawaban responden cenderung mengarah ke nilai tertinggi yang artinya responden cenderung memiliki kemampuan pengguna yang baik. Standar deviasi pada variabel kemampuan pengguna sebesar0,51253. Hal ini menunjukan standar penyimpangan data terhadap nilai rata-ratanya adalah 0,51253

Keterlibatan Pengguna $\left(\mathrm{X}_{2}\right)$ memiliki nilai minimum sebesar 1,75 pada data nomor 13, serta nilai maksimum sebesar 3,75 pada data nomor 3,12,26 dengan 
nilai rata - rata 28,3menunjukan jawaban responden cenderung mengarah ke nilai tertinggi yang artinya responden cenderung memiliki keterlibatan pengguna yang baik. Standar deviasi pada variabel keterlibatan pengguna sebesar0,58439. Hal ini menunjukan standar penyimpangan data terhadap nilai rata-ratanya adalah0,58439.

Kinerja SIPKD (Y) memiliki nilai minimum sebesar 2,15 pada data nomor 5, serta nilai maksimum sebesar 3,92 pada data nomor 23,23,25 dengan nilai ratarata 31,3 menunjukan jawaban responden cenderung mengarah ke nilai tertinggi yang artinya responden cenderung menunjukan peningkatan kinerja SIPKD yang baik. Standar deviasi pada variabel kinerja SIPKD sebesar 0.45981. Hal ini menunjukan standar penyimpangan data terhadap nilai rata-ratanya adalah0.45981.

Uji normalitas menggunakan uji Kolmogorov-Smirnov, dengan uji ini dapat diketahui data yang digunakan berdistribusi normal atau tidak. Apabila Sign t hitung $>0.05$, maka data tersebut berdistribusi normal dan begitu juga sebaliknya (Santoso, 2001).

Tabel 5.

Hasil Uji Normalitas

\begin{tabular}{cc}
\hline & Unstandardized Residual \\
\hline $\mathrm{N}$ & 40 \\
Kolmogorov-Smirnov $Z$ & 0,588 \\
Asymp.Sig.(2-tailed) & 0,880 \\
\hline
\end{tabular}

Sumber: Data diolah, 2018

Berdasarkan uji normalitas seperti yang terlihat pada Tabel 5. nilai Kolmogorov-Smirnov, menunjukkan bahwa nilai Asymp. Sig (2-tailed) 0,880 lebih besar dari level of significant, yaitu 5 persen $(0,05)$ sehingga data yang diuji menyebar normal atau berdistribusi normal.

Uji multikolinieritas digunakan untuk mengetahui apakah antara variabel bebas terjadi multikolinieritas atau tidak. Uji yang digunakan yaitu dengan 
melihat nilai VIF (Varian Inflation Factor) dan Tolerance pada proses regresi biasa, jika keduanya mendekati 1 atau besaran VIF kurang dari 10 maka model tidak terkena multikolinieritas. Berdasasrkan hasil pengujian multikolinearitas dapat diperoleh hasil sebagai berikut.

Tabel 6.

Hasil Uji Multikolinearitas

\begin{tabular}{rcc}
\hline Variabel & Tolerance & VIF \\
\hline Kemampuan Pengguna $\left(\mathrm{X}_{1}\right)$ & 0,541 & 1,849 \\
Keterlibatan Pengguna $\left(\mathrm{X}_{2}\right)$ & 0,541 & 1,849 \\
\hline
\end{tabular}

Sumber: Data diolah, 2018

Berdasarkan Tabel 6. dapat disimpulkan bahwa nilai tolerance persamaan regresi linear berganda masing-masing variabel bernilai diatas $10 \%(0,10)$ dan nilai VIF dibawah 10. Hal ini menunjukkan bahwa model regresi yang ada tidak terjadi gejala multikolinearitas.

Uji Heterokedastisitas dilakukan untuk menguji apakah dalam model regresi terjadi ketidaksamaan varian dari residu satu pengamatan ke pengamatan lain. Model regresi yang baik adalah model homokedastisitas atau tidak terjadi heterokedastisitas. Apabila model suatu regresi mengandung gejala heterokedastisitas, maka hasil yang diberikan akan menyimpang. Untuk mengetahui apakah sebuah regresi memiliki indikasi heterokedastisitas, maka masalah tersebut bisa dideteksi dengan menggunakan uji Glejser Test. Jika probabilitas signifikansinya di atas 0,05 maka dapat dikatakan bahwa pada model regresi tidak mengandung masalah heterokedastisitas . Hasil uji heterokedastisitas dapat dilihat pada Tabel 7. 
Tabel 7.

Hasil Uji Heteroskedastisitas

\begin{tabular}{lccccc}
\hline \multicolumn{1}{c}{ Model } & \multicolumn{2}{c}{ Unstandardized Coefficients } & Standardized Coefficients & $\mathrm{t}$ & Sig. \\
& $\mathrm{B}$ & Std. Error & Beta & & \\
\hline (Constant) & .403 & .121 & & 3.341 & .002 \\
Kemampuan & -.102 & .053 & -.404 & -1.930 & .061 \\
Keterlibatan & .018 & .046 & .083 & .398 & .693 \\
\hline Sumber: Data diolah, 2018 & & & &
\end{tabular}

Tabel 7. menunjukkan bahwa nilai sigifikansi dari variabel kemampuan pengguna sebesar 0,061 , keterlibatan pengguna sebesar 0,693 . Nilai tersebut lebih besar dari 0,05 yang berarti tidak terdapat pengaruh antara variabel bebas terhadap absolute residual. Dengan demikian, model yang dibuat tidak mengandung gejala heteroskedastisitas.

Analisis regresi linier berganda ini digunakan untuk menganalisis pengaruh kemampuan pengguna $\left(\mathrm{X}_{1}\right)$, keterlibatan pengguna $\left(\mathrm{X}_{2}\right)$, terhadap kinerja SIPKD (Y). Hasil analisis regresi dapat dilihat pada Tabel 8. sebagai berikut.

Tabel 8.

Hasil Uji Regresi Linear Berganda

\begin{tabular}{|c|c|c|c|c|c|c|}
\hline \multirow{2}{*}{\multicolumn{2}{|c|}{ Model }} & \multicolumn{2}{|c|}{$\begin{array}{c}\text { Unstandardized } \\
\text { Coefficients }\end{array}$} & \multirow{2}{*}{$\begin{array}{c}\text { Standardized } \\
\text { Coefficients }\end{array}$} & \multirow[b]{2}{*}{$\mathrm{t}$} & \multirow[b]{2}{*}{ Sig. } \\
\hline & & $\mathrm{B}$ & Std. Error & & & \\
\hline \multirow[t]{6}{*}{1} & (Constant) & .669 & .198 & & 3.374 & .002 \\
\hline & Kemampuan pengguna & .550 & .087 & .613 & 6.333 & .000 \\
\hline & Keterlibatan pengguna & .287 & .076 & .365 & 3.765 & .001 \\
\hline & Adjusted R Square & 0,802 & & & & \\
\hline & $\mathrm{F}$ & 80,065 & & & & \\
\hline & Sig. & $.000^{\mathrm{a}}$ & & & & \\
\hline
\end{tabular}

Sumber: Data diolah, 2018

Berdasarkan Tabel 8. dapat disusun persamaan regresi sebagai berikut :

$$
Y=0,669+0,550 X_{1}+0,287 X_{2}+\varepsilon
$$

Interpretasi dari persamaan di atas adalah nilai konstanta sebesar 0,669 yaitu jika nilaikemampuan pengguna dan keterlibatan pengguna sama dengan nol, maka nilai kinerja SIPKD adalah sebesar 0,669. Koefisien regresi $\left(b_{1}\right)$ pada kemampuan pengguna $\left(X_{1}\right)$ bernilai 0,550 mempunyai hubungan positif terhadap kinerja SIPKD. Artinya, bila nilai kemampuan pengguna $\left(\mathrm{X}_{1}\right)$ bertambah, maka kinerja 
SIPKD (Y) akan mengalami peningkatan sebesar 0,550 dengan asumsi variabel bebas lainnya konstan. Koefisien regresi $\left(b_{2}\right)$ pada keterlibatan pengguna $\left(X_{2}\right)$ bernilai 0,287 mempunyai hubungan positif terhadap kinerja SIPKD. Artinya, bila nilai keterlibatan pengguna $\left(\mathrm{X}_{2}\right)$ bertambah, maka kinerja SIPKD (Y) akan mengalami peningkatan sebesar 0,287 dengan asumsi variabel bebas lainnya konstan.

Berdasarkan Tabel 8. menunjukkan bahwa koefisien determinasi yaitu nilai adjusted $\mathrm{R}^{2}$ adalah sebesar 0,802 mempunyai arti bahwa sebesar $80,2 \%$ variasi kinerja SIPKD terhadap Dinas Pariwisata Provinsi Bali dipengaruhi oleh variasi kemampuan pengguna dan keterlibatan pengguna, sedangkan sisanya sebesar 19,8\% djelaskan oleh faktor lain yang tidak dimasukkan ke dalam model.

Uji kelayakan model atau yang lebih populer disebut sebagai uji $\mathrm{F}$ merupakan tahapan awal mengidentifikasi model regresi yang diestimasi layak atau tidak. Hasil uji regresi dinyatakan layak apabila memiliki nilai signifikansi uji F kurang dari 0,05. Hasil uji F (F test) pada Tabel 8. menunjukkan bahwa nilai F hitung sebesar 80,065 dengan nilai signifikansi $\mathrm{P}$ value 0,000 yang lebih kecil dari $\alpha<0,05$. Hal ini menunjukan model yang digunakan pada penelitian ini adalah layak.

Uji t dalam penelitian ini bertujuan untuk menguji apakah masing-masing variabel bebas $(\mathrm{X})$ yang digunakan dalam model regresi memiliki pengaruh pada variabel terikat $(Y)$. Apabila nilai signifikansinya > 0,05 maka hipotesis ditolak (koefisien regresi tidak signifikan), dan apabila nilai signifikansi $\leq 0,05$ maka hipotesis diterima (koefisien regresi signifikan). 
Pada tabel 8. dapat dilihat bahwa hasil analisis pengaruh kemampuan pengguna terhadap kinerja SIPKD diperoleh nilai signifikansi sebesar 0,000 dengan nilai koefisien beta 0,613 . Nilai signifikansi $0,000<0,05$ mengindikasikan bahwa $\mathrm{H}_{0}$ ditolak dan $\mathrm{H}_{1}$ diterima. Hasil ini menunjukan bahwa kemampuan pengguna berpengaruh positif dan signifikan terhadap kinerja SIPKD yang artinya semakin baik kemampuan teknik dan analisis yang dimilikioleh pengguna SIPKD akan meningkatkan output kinerja dari SIPKD di Dinas Pariwisata Provinsi Bali.

Berdasarkan hasil statistik deskriptif, pernyataan hasil kuisoner dengan nilai rata-rata jawaban tertinggi untuk variabel kemampuan pengguna adalah item ketiga yaitu "Saya memiliki kemampuan dalam teknik analisis yang berhubungan dengan organisasi" hal ini menunjukan bahwa pengguna SIPKD di Dinas Pariwisata Provinsi Bali memiliki kemampuan dalam teknik dalam analisis yang baik sehingga meningkatkan kinerja SIPKD.Hasil penelitian ini konsisten dengan hasil penelitian Kharisma (2017), Perbarini dan Juliarsa (2012), Daryani (2013) yaitu kemampuan pengguna memiliki pengaruh yang positif dan signifikan terhadap kinerja sistem informasi akuntansi.

Pada tabel 8. dapat dilihat bahwa hasil analisis pengaruh keterlibatan pengguna terhadap kinerja SIPKD diperoleh nilai Signifikansi sebesar 0,001 dengan nilai koefisien beta 0,365 . Nilai Signifikansi $0,001<0,05$ mengindikasikan bahwa $\mathrm{H}_{0}$ ditolak dan $\mathrm{H}_{2}$ diterima. Hasil ini menunjukan bahwa keterlibatan pengguna berpengaruh positif dan signifikan terhadap kinerja SIPKD terhadap Dinas Pariwisata Provinsi Bali yang artinya semakin tinggi keterlibatan pengguna dalam penyusunan dan pemakaian SIPKD maka berdampak pada 
efektivitas penerapan SIPKD yang mendorong peningkatan kualitas kinerja menjadi semakin baik di Dinas Pariwisata Provinsi Bali.

Berdasarkan hasil statistik deskriptif, pernyataan hasil kuisoner dengan nilai rata-rata jawaban tertinggi untuk variabel keterlibatan pengguna adalah item kedua yaitu“Saya bersedia menggunakan sistem informasi pengelolaan keuangan daerah yang dioperasikan di tempat saya bekerja" hal ini menunjukan bahwa kemauan atau keinginan yang tinggi untuk berpartisipasi dalam penggunaan SIPKD sehingga mendorong efektivitas penerapan SIPKD di Dinas Pariwisata Provinsi Bali. Hasil penelitian ini konsisten dengan hasil penelitian Kharisma (2017), Surya dan Suardikha (2016), Perbarini dan Juliarsa (2012) yaitu keterlibatan pengguna memiliki pengaruh yang positif dan signifikan terhadap kinerja sistem informasi akuntansi.

\section{SIMPULAN}

Berdasarkan pembahasan hasil penelitian di atas, dapat disimpulkan bahwa kemampuan pengguna dan keterlibatan pengguna berpengaruh positif dan signifikan terhadap kinerja SIPKD di Dinas Pariwisata Provinsi Bali. Sedangkan saran yang dapat diberikan yaitu Kepala Dinas Pariwisata Provinsi Bali diharapkan mampu memberikan pelatihan, workshop atau diklat bagi pengguna SIPKD sehingga diharapkan pengguna sistem mau meningkatkan teknik personal yang dimiliki dan dapat mempermudah pengguna sistem itu sendiri dalam mengaplikasikan sistem yang ada. Selain itu Kepala Dinas Pariwisata Provinsi Bali sebaiknya lebih banyak mendorong pegawai untuk lebih banyak terlibat agar lebih meningkatkan kinerja sistem informasi pengelolaan keuangan daerah, 
khususnya pada aspek yang perlu ditingkatkan dalam keterlibatan pemakai yaitu keikut sertaan pegawai dalam perencanaan sistem informasi pengelolaan keuangan daerah yang dioperasikan di Dinas Pariwisata Provinsi Bali.

\section{REFERENSI}

Almilia, L. S. and Briliantien, I. 2007. 'Faktor-Faktor Yang Mempengaruhi Kinerja Sistem Informasi Akuntansi Pada Bank Umum Pemerintah Di Wilayah Surabaya Dan Sidoarjo'.

Ariani, A. M. 2017. 'Pengaruh Kualitas Sumber Daya Manusia (SDM), Perencanaan Anggaran Dan Teknologi Informasi Terhadap Kinerja Keuangan Pemerintahan Daerah Tabanan', Tesis. Fakultas Ekonomi Universitas udayana, p. 2017.

Artanaya, P. Y. 2016. 'Pengaruh Partisipasi Pemakai Terhadap Kinerja Sistem Informasi Akuntansi Dengan Kemampuan Pemakai Sebagai Variabel Moderasi', E-Jurnal Akuntansi Universitas Udayana Vol.15.2. Mei (2016): 1482-1509 ISSN: 2302-8556, 15, pp. 1482-1508.

Aziz, A. 2003.Accounting Information System Satisfaction and Job Satisfaction Among Malaysian Accountants. 7th Pacific Asia Conference on Information Systems, 10-13 July 2003. Adelaide, South Australia.

Badudu, M. Z. 2001.Kamus Umum Bahasa Indonesia. Pustaka Si. Jakarta.

Bodnar, G. N. and Hopwood., William, S. 2000.Sistem Informasi akuntansi, buku satu.

Choe, J. M. 1996. 'The Relationship Among Performance of Accounting Information Systems, Influence Factors and Evolution Level of Information Systems', Journal of Management Information Systems, 12 (4), pp. 215239.

Devi, S. 2014. 'Analisis technology acceptance model (tam) terhadap penggunaan sistem informasi di nusa indah beach hotel \& spa fakultas ekonomi dan bisnis universitas udayana ( unud ), bali , indonesia fakultas ekonomi', $E$ Jurnal Akuntansi Universitas Udayana, 1, pp. 167-184.

Dominggus, P. et al. 2013. 'Pengaruh Penggunaan Sistem Informasi Pengelolaan Keuangan Daerah (SIPKD) Terhadap Kinerja Pegawai Di Kabupaten Tana Toraja', 2(2), pp. 183-192. 
Galang Rahadian Prabowo, A. M. 2014. 'Faktor-Faktor yang Mempengaruhi Kinerja Sistem Informasi Akuntansi', Accounting Analysis Journal, 3(1).

Ghozali, I. 2013. 'Analisis Multivariate dengan program IBSM SPSS21', Semarang: Universitas Diponegoro.

Goldfinch, S. 2007. 'Pessimism, Computer Failure, and Information Systems Development in the Public Sector', Public Administration Review, pp. 917926.

Gomes, R. C., Alfinito, S. and Albuquerque, P. H. 2013. 'Analyzing Local Government Financial Performance: Evidence from Brazilian Municipalities 2005-2008', Rac, 17(4), pp. 704-719. doi: 10.1590/S141565552013000600005.

Handayani, R. 2007. 'Analisis Faktor-Faktor yang Mempengaruhi Minat Pemanfaatan Sistem Informasi dan Penggunaan Sistem Informasi ( Studi Empiris Pada Perusahaan Manufaktur di Bursa Efek Jakarta )', Jurnal Akuntansi danKeuangan, 9(2), pp. 76-88.

Harash, E., Al-Timimi, S. and Radhi, A. H. 2014. 'The Influence of Accounting Information Systems (AIS) on Performance of Small and Medium Enterprises (SMEs) in Iraq', Journal of Business and Management, 3(4), pp. 48-57. doi: 10.12735/jbm.v3i4p48.

Indriantoro, N. and Supomo, B. 2013.Metodologi Penelitian Bisnis untuk Akuntansi dan Manajemen. Edisi Pert. Yogyakarta: BPFE.

Ives, B., Olson, M. H. and Baroudi, J. J. 1983. 'The measurement of user information satisfaction', Communications of the ACM, 26(10), pp. 785793. doi: $10.1145 / 358413.358430$.

Kharisma, I. A. M. 2017. 'Pengaruh Keterlibatan Pemakai, Kemampuan Pemakai, Pelatihan Dan Pendidikan Pemakai Terhadap Kinerja Sistem Informasi Akuntansi', E-Jurnal Akuntansi Universitas Udayana, 19.3, pp. 2527-2555.

Komara, A. 2005. 'Analisis Faktor-Faktor Yang Mempengaruhi Kinerja Sistem Informasi Akuntansi Drs. Acep Komara, Se., Msi. Universitas Swadaya Gunung Jati Cirebon', Jurnal SNA 8, (September), pp. 15-16.

Lilis Puspitawati, S. D. A. 2011.Sistem Informasi Akuntansi. Yogyakarta: Graha Ilmu.

Margan Kesumman, P.2016. 'Pengaruh Penggunaan Sistem Informasi Pengelolaan Keuangan Daerah Terhadap Kinerja Pegawai Pada Satuan Kerja Perangkat Daerah Di Pemerintahan Kota Denpasar', E-Jurnal Akuntansi Universitas Udayana, 15.2. 
Murty, W. A. and Hudiwinarsih, G. 2012. 'Pengaruh Kompensasi, Motivasi dan Komitmen Organisasional', 2(2), pp. 215-228. doi: 10.14414/tiar.v2i02.97.

Napitulu, I. H. 2015. 'Antecedence of user satisfaction in management accounting information systems quality: user involvement and user competency (survey of indonesia manufacture company managers)', I $J A B E$, Vol. 13, $\mathrm{N}($ Politeknik Negeri Medan - Indonesia and Padjadjaran University), pp. 561-577.

Perbarini, N. K. A. and Juliarsa, G. 2012. 'Analisis Faktor-faktor yang Mempengaruhi Kinerja Sistem Informasi Akuntansi pada LPD di Kecamatan Denpasar Utara', Fakultas Ekonomi Universitas Udayana.

Rusmiati, R. 2012. 'Pengaruh Keterlibatan Pengguna, Kapabilitas Personal Sistem Informasi, Ukuran Organisasi, dan Formalisasi pengembangan Sistem Terhadap Kepuasan Pengguna Sistem Informasi Akuntansi', Skripsi, (Universitas Muhhamadyah Surakarta).

Sekaran, U., \& Bougie, R. 2016. 'Research methods for business: A skill building approach, Long Range Planning'. doi: 10.1016/0024-6301(93)90168-F.

Setyowati, D.2008. 'Faktor-Faktor Yang Mempengaruhi Kinerja Sistem Informasi Akuntansi Pada Bank Perkreditan Rakyat Di Wilayah Karangayar', Fakultas Ekonomi Universitas Muhammadiyah Surakarta.

Soegiharto. 2001. 'Influence Factors Affecting The Performance Of Accounting Information System', Journal International of Business, Vol. III N, pp. 177202.

Stephen Robbins. 2008.Organizational Behaviour. Salemba Em. Jakarta.

Suarta, I. M. and Sudiadnyani, I. G. A. 2014. 'Studi Faktor Penentu Penerimaan Dan Penggunaan Sistem Informasi Akuntansi Pada Lembaga Perkreditan Desa', Jurnal Sistem Informasi, 10 (1).

Sugiyono. 2014.Metode Penelitian Bisnis. Edited by Alfabeta. Bandung.

Surya, M. and Suardhika, S. 2016. 'Faktor-faktor Yang Berpengaruh Pada Kepuasan Pemakai Sistem Informasi Akuntansi Lembaga Perkreditan Desa Di Kecamatan Mengwi', E-Jurnal Akuntansi Universitas Udayana, 15(1), pp. 317-348.

Susanto, A. 2001.Sistem Informasi Akuntansi 1: Pendekatan Sistem Praktik penyusunan, metode dan prosedur. Bandung:

Swandewi, P. and Dodik, A. 2017. 'Kepuasan Pengguna Sistem Informasi Akuntansi pada Lembaga Perkreditan Desa di Kabupaten Buleleng', EJurnal Akuntansi Universitas Udayana, 19.3, pp. 1803-1831. 
Terry, J. and Standing, C. 2004. 'The value of user participation in E-commerce systems development', Informing Science, 7, pp. 31-45.

Tjhai Fung Jen. 2002. 'Faktor-Faktor Yang Mempengaruhi Kinerja Sistem Informasi Akuntansi', Jurnal Bisnis dan Akuntansi, IV No. 2.

Trenida, Tata. 2018. 'Dukungan Manajemen Puncak Memoderasi Pengaruh Keterlibatan Pengguna dan Kemampuan Pengguna Pada Kinerja Sistem Informasi Akuntansi', E-Jurnal Akuntansi Universitas Udayana, 23, pp. 1844-1869.

Vaughan, P. 2001. 'System Implementation Success Factors; It's not just the Technology', Journal of The University of Colorado at Boulder.

Wahyono Teguh. 2005.Sistem Informasi: Konsep Dasar, Analisis Desain dan Implementasi. Jakarta

Wansyah, H., Darwanis and Usman Bakar. 2012. 'Pengaruh Kapasitas Sumber Daya Manusia, Pemanfaatan Teknologi Informasi dan Kegiatan Pengendalian Terhadap Nilai Informasi Pelaporan Keuangan SKPD pada Provinsi Aceh.', Jurnal Akuntansi Pascasarjana Universitas Syiah Kuala Bandar Aceh, 1(1), pp. 43-58.

Wilkinson, Joseph W.2000. Accounting Information System.Frouth Edition. United States New York: John Wiley and Sons Inc.

www.djkd.kemendagri.go.id diakses pada 28 september 2018.

Yoon, Y.K. dan Im, K.S. 2005.'An Evaluation system for IT Outsourcing Costumer Satisfaction Using the Analytic Hierarchy Process (AHP)'.Journal of Global Information Management, 13(4), 55-78. 